\title{
NOVOS REQUISITOS PARA CONCESSÃO DA PENSÃO POR MORTE AO CÔNJUGE/COMPANHEIRO NO CONTEXTO DE CRISE DO ESTADO- PROVIDÊNCIA UMA INTERFACE ENTRE SEGURIDADE SOCIAL E DIREITO DE FAMÍLIA
}

\section{NUEVOS REQUISITOS PARA CONCESIÓN DE LA PENSIÓN POR MUERTE AL CÓNYUGE/PAREJA EN EL CONTEXTO DE CRISIS DEL ESTADO DE BIENESTAR SOCIAL INTERFACE ENTRE SEGURIDAD SOCIAL E DERECHO DE FAMILIA}

\begin{abstract}
${ }^{1}$ Laira Carone Rachid Domith
RESUMO

A partir de uma pesquisa qualitativa, interdisciplinar, essencialmente bibliográfica e documental, o presente estudo, apresentando a crise do Estado-Providência enquanto contexto em que se assiste a imposição de maior rigor para a concessão de benefícios previdenciários, tem como foco a análise das novas regras trazidas pela Lei 13.135/2015, especificamente as referentes à concessão da pensão por morte ao cônjuge/companheiro. A partir da construção de um paralelo entre a pensão por morte, inerente ao Direito Previdenciário, e o instituto da pensão alimentícia, inerente ao Direito de Família, foi feita uma reflexão crítica acerca dos requisitos atuais para concessão daquele benefício. Demonstrou-se que a atual pensão por morte em muito se assemelha à pensão alimentícia temporária fixada entre ex-cônjuges e excompanheiros, devendo nesta se inspirar para que a reforma da Previdência seja feita de forma coerente com seu objetivo de contenção/redução de gastos, mas comprometida com a dignidade daqueles que se mostrarem verdadeiros dependentes do segurado falecido.
\end{abstract}

Palavras-chave: Estado de bem-estar social, Lei 13.135/2015, Pensão por morte, Dependência econômica, Pensão alimentícia temporária

\section{RESUMEN}

Mediante una investigación cualitativa, interdisciplinar, esencialmente bibliográfica y documental, este estudio, presentando la crisis del Estado de Bienestar Social como el contexto en que asistimos a la imposición de mayor rigor para la concesión de prestaciones de seguridad social, se centra en el análisis de las nuevas normas introducidas por la Ley 13.135/2015, específicamente las que se refieren a la concesión de la pensión por fallecimiento de cónyuge/pareja. A partir de la construcción de un paralelo entre la pensión por fallecimiento, inherente a la Ley de Seguridad Social y el instituto de la pensión alimenticia, inherente al Derecho de Familia, se hizo una reflexión crítica sobre los requisitos actuales para la concesión de dicho beneficio. Se ha demostrado que la actual pensión por muerte es muy similar a la pensión alimenticia temporal fijo entre los ex-cónyuges y ex-parejas, debiendo en esta estar inspirada para que la reforma de la Seguridad Social pueda ocurrir de una manera coherente con su objetivo de contención/reducción de gastos, pero comprometida con la dignidad de aquellos que muestran verdaderos dependientes de la persona fallecida.

Palabras-claves: Estado de bienestar social, Ley 13.135/2015, Pensión por muerte, Dependencia económica, Pensión alimenticia temporal

\footnotetext{
${ }^{1}$ Mestre em Direito pela Universidade Estácio de Sá - UNESA, São Paulo (Brasil). Professora de Graduação em Direito na Faculdade Doctum de Juiz de Fora, Minas Gerais (Brasil). E-mail: lairarachid@ hotmail.com
} 


\section{INTRODUÇÃO}

Conforme consabido, no Brasil a Seguridade Social é composta pela Saúde, Assistência Social e Previdência Social (art. 194, CF/88), sendo esta destinada a resguardar o direito dos trabalhadores e de seus dependentes quando encontram-se expostos a situações de risco social, tais como doenças, acidentes, idade avançada, maternidade, reclusão e morte.

Risco social pode ser conceituado como um perigo que ameaça o indivíduo e ultrapassao, "atingindo toda a coletividade, fazendo surgir a necessidade social. Cabe à previdência social a função de aliviar a necessidade social surgida em virtude da ocorrência dos eventos previamente selecionados, garantindo uma tutela de base (mínimo vital)" (SANTOROPASSARELLI apud HORVATH JÚNIOR, 2004, p. 27).

Em outras palavras, risco social é "todo evento coberto pelo sistema protetivo, com o intuito de fornecer ao segurado algum rendimento substituidor de sua remuneração, como indenização por seqüelas ou em razão de encargos familiares” (IBRAHIM, 2015, p. 28).

Atualmente, a legislação brasileira prevê os seguintes benefícios previdenciários: aposentadoria por invalidez, aposentadoria por idade, aposentadoria por tempo de contribuição, aposentadoria da pessoa com deficiência, aposentadoria especial por exposição a agentes nocivos, auxílio-doença, salário-família, salário-maternidade, auxílio-acidente, pensão por morte, auxílio-reclusão, serviço social, habilitação e reabilitação profissional e abono anual. Estes dois últimos são serviços colocados à disposição do cidadão e não prestações pagas em dinheiro.

O presente estudo tem como objetivo aprofundar-se, com exclusividade, no benefício da pensão por morte, mais precisamente em seu novo regramento a partir da entrada em vigor da Lei 13.135/2015, traçando apontamentos críticos sobre os requisitos para sua concessão aos cônjuges e companheiros.

Considerando que a justificativa para concessão do referido benefício é a dependência econômica com relação ao segurado falecido, impossível pensar no instituto sem lembrar da pensão alimentícia, embora esta não se situe no âmbito do Direito Previdenciário, mas na seara do Direito de Família.

Pretende-se demonstrar que a Lei 13.135/2015 não levou em conta o princípio da solidariedade familiar ao estipular que a pensão por morte será devida por apenas 4 meses ao cônjuge/companheiro supérstite caso sua união com o segurado não tenha atingido a duração 
mínima de 2 anos. Ademais, se a presunção de dependência econômica entre ex-cônjuges/excompanheiros não existe para fins de concessão de pensão alimentícia, por que existiria no âmbito Previdenciário, já que o objetivo da nova regulamentação é justamente desonerar a Previdência Social e realizar o equilíbrio atuarial? Mais uma crítica refere-se à criação da tabela que atrelou o lapso temporal de desfrute da pensão por morte à idade do beneficiário quando do óbito do segurado.

Por fim, a partir de uma pesquisa qualitativa, interdisciplinar, essencialmente bibliográfica e documental, demonstrar-se á que o Direito de Família pode contribuir para o aperfeiçoamento do Direito Previdenciário no que concerne ao benefício da pensão por morte, mormente em tempos de crise do Estado-Providência e da manifesta má-fé de alguns cidadãos que simulam uniões estáveis e casamentos apenas para receberem tal benefício, fraudando a Previdência Social.

\section{BREVES CONSIDERAÇÕES SOBRE A CRISE DO ESTADO-PROVIDÊNCIA E A REFORMA PREVIDENCIÁRIA NO BRASIL}

Estado-Providência ou Estado de Bem-Estar Social é uma forma de organização política e econômica em que o Estado atua como organizador da economia para fins de promoção social. Neste Estado há um esforço deliberado do poder organizado para modificar o jogo das forças do mercado em três sentidos:

Primeiro, garantindo aos indivíduos e às famílias uma renda mínima, independentemente do valor de mercado de seu trabalho ou de sua propriedade; segundo, reduzindo a exposição à insegurança, colocando os indivíduos e famílias em condições de enfrentar certas contingências sociais que, de outro modo, levariam a crises do indivíduo ou de sua família; e terceiro, assegurando que a todos os cidadãos, sem distinção de status ou classe, sejam oferecidos os mais altos padrões de um conjunto reconhecido de serviços sociais (BRIGGS apud BENEVIDES, 2011, p. 13)

Em outras palavras, o fundamento do Estado de Bem-Estar Social é "a existência de um padrão mínimo (garantido pelo Estado) de renda, alimentação, saúde, alojamento e instrução, assegurado a qualquer cidadão como um direito político e não como caridade" (WILENSKI apud BENEVIDES, 20122, p. 13) 
Quando se debruça sobre a temática do Estado de Bem-Estar Social em termos mundiais, a doutrina especializada faz referência, espacial e cronologicamente, a alguns marcos como a Lei dos Pobres, editada em 1600 pela Coroa Real Britânica para combater o crescimento dos índices de pobreza e desemprego; a Declaração dos Direitos do Homem e do Cidadão (1789), berço moderno dos direitos fundamentais, que contribuiu para a eclosão da primeira fase da Revolução Francesa; o primeiro Sistema de Seguro Social implementado pelo Chanceler Otto Von Bismarck na Alemanha (1880), que instituiu os seguros contra doenças, acidentes, invalidez e velhice; a doutrina do Welfare State ${ }^{l}$ adotada por Franklin Delano Roosevelt nos Estados Unidos da América para combater a crise de 1929, bem como o Social Security Act, aprovado em 1935 para estimular o consumo através de ajuda aos idosos e do auxílio-desemprego; o Plano Beveridge que passou a vigorar na Inglaterra em 1941 com o objetivo de financiar o sistema de seguridade social através da cobrança compulsória de contribuições sociais; e a Declaração Universal dos Direitos do Homem², adotada pela Organização das Nações Unidas em 1948.

Descrever a evolução do Estado de Bem-Estar Social no mundo não constitui objetivo do presente estudo, que se aterá ao contexto brasileiro. Primeiramente, frise-se que existem correntes doutrinárias que afirmam ter o Brasil conquistado o status de um Estado de Bem-Estar Social e, outras, um Estado de Bem-Estar Social em construção, discussão esta que também não é foco deste artigo, nem influenciará em seu desenvolvimento. A explanação sobre o Estado Providência será feita de forma panorâmica, bem como a abordagem da crise que o acomete, servindo de substrato para justificar a Reforma da Previdência e, portanto, a edição de leis como a 13.135/2015 que estabelecem maior rigor para a concessão de benefícios.

A história do Estado de Bem-Estar Social no Brasil tem início em 1930, através do Golpe liderado por Getúlio Vargas. Com a implementação da República assistiu-se à introdução de políticas sociais nacionais envolvendo as legislações trabalhista e previdenciária em atendimento aos pontos principais da lista de reivindicações do movimento operário, dentre os

\footnotetext{
1 O Estado mínimo foi substituído pelo "Estado de tamanho certo", ou seja, aquele que além das demandas sociais elementares propiciaria igualdade de oportunidade para todos sem, contudo, transmutar-se em um Estado comunista (IBRAHIM, 2015, p. 3). Aliás, pode-se afirmar que "o Estado de Bem-Estar Social surgiu muito mais como um contraponto necessário ao crescimento do comunismo, do que propriamente pela conscientização dos dirigentes mundiais pela importância da proteção social" (IBRAHIM, 2015, p. 4).

2 Artigo 25, item 1. Todo ser humano tem direito a um padrão de vida capaz de assegurar a si e a sua família saúde e bem estar, inclusive alimentação, vestuário, habitação, cuidados médicos e os serviços sociais indispensáveis, e direito à segurança em caso de desemprego, doença, invalidez, viuvez, velhice ou outros casos de perda dos meios de subsistência fora de seu controle.
}

Revista de Direitos Sociais, Seguridade e Previdência Social| e-ISSN: 2525-9865 | Minas Gerais | v. 1 | n. 2 | p. 158 - 187 | Jul/Dez. 2015. 
quais a limitação da jornada de trabalho a oito horas; o repouso remunerado e a regulamentação do trabalho de mulheres.

Contudo, apesar de o Estado passar a intervir nas relações entre capital e trabalho antes adstritas a contratos individuais e particulares de trabalho -, a distribuição de direitos ignorava trabalhadores em situação de informalidade e "causas não vinculadas aos riscos do trabalho ficaram praticamente sem patrocínio, como a saúde pública, o saneamento, a educação, a habitação, e tiveram evolução ainda mais lenta" (KERSTENETZKY, 2012, p. 180).

\begin{abstract}
Considerando-se que estava em marcha um esforço de industrialização por substituição de importações, haveria que se ponderar não apenas as novas oportunidades criadas e os riscos ordinários envolvidos com a expansão do assalariamento, mas também os riscos sociais ocasionados pelos próprios planos de desenvolvimento, como a urbanização acelerada e descontrolada. (...) a aposta era na incorporação social via mercado de trabalho, o que se revelou uma aposta arriscada dada a realidade da imensa informalidade que frutificou ao lado do trabalho regulamentado. (...) Não obstante politicamente fracassada, é visível no período talvez a mais genuína tentativa de inflexão do modelo de bem-estar em direção a iniciativas universalistas redistributivistas (...) (KERSTENETZKY, 2012, p. 180).
\end{abstract}

Na sequiência dos acontecimentos históricos, o Regime Militar foi instaurado em 1964 e com ele significativas garantias em termos de universalização das políticas sociais e de proteção aos trabalhadores rurais, à empregada doméstica e aos autônomos. A incorporação desta vasta clientela aos serviços sociais não foi acompanhada por uma expansão econômica proporcional, de forma que a universalização da seguridade social foi implementada parcialmente, direcionada aos pobres. A universalização propriamente dita só ocorreu a partir da Constituição Federal de 1988.

Considerando que no Brasil a industrialização se deu de forma tardia e, também, o fato de o cenário político ter sido turbulento da segunda metade da década de 60 até meados da década de 80, o período de redemocratização, marcado pela promulgação da Constituição Federal de 1988, encontrou o país em situação de penúria (GARLAND, 2008, p. 12).

Os Governos Collor e Cardoso, apesar de terem avançado em termos de Saúde e Assistência Social, promoveram reformas de cunho fiscal na Previdência Social (uma das principais fontes de déficits fiscais) e na Educação (enfatizou-se o nível Fundamental). A política que norteou o Governo Cardoso teve como tônica a meta de crescimento econômico a partir da retração do Estado e da abertura comercial.

Revista de Direitos Sociais, Seguridade e Previdência Social| e-ISSN: 2525-9865 | Minas Gerais | v. 1 | n. 2 | p. 158 - 187 | Jul/Dez. 2015. 
Apesar do êxito do Plano Real no combate à inflação e na diminuição da pobreza, a desigualdade social aumentou, donde se conclui que os serviços destinados à promoção do Estado de Bem-Estar Social não promoveram mudanças estruturais na sociedade.

Tal fato faz com que alguns doutrinadores afirmem que com relação à efetivação de uma verdadeira política de bem-estar social prevalece a concepção de que o Brasil nunca chegou a vivenciar o Estado de Bem-Estar Social, "nem sequer chegou a constituir este projeto como prioridade de Estado ou de governos" (RAMOS, 2010, p. 3465):

O princípio do mérito constitui a base sobre a qual se ergue o sistema brasileiro de política social, além do que como a relação renda-contribuição-benefício segue dominante as políticas sociais, na sua maioria, reproduzem o sistema de desigualdades predominante na sociedade (AURELIANO; DRAIBE apud FIORI, 1997, p. 129).

No Governo Lula, em um primeiro momento, as políticas em prol do Estado de BemEstar Social ganharam relevo, tendo como novidade um novo modo de interação entre as políticas sociais e as políticas econômicas. Segundo Kerstenetzky,

O país testemunhou uma aceleração do crescimento baseada em boa medida na expansão das políticas e dos gastos sociais, especialmente as transferências governamentais e a valorização do salário mínimo, com resultados inéditos em termos de redução consistente da pobreza e da desigualdade. Pode-se afirmar que a inovação principal se traduziu na aposta na possibilidade de o gasto social contribuir não apenas para o alcance de direitos, como também para relaxar suas próprias condições de financiamento, tornando o orçamento social de certo modo endógeno à própria política social (2012, p. 231-232).

Contudo, a segunda fase do Governo Lula priorizou a estabilidade econômica e, para seu êxito, as políticas monetária e fiscal foram instrumentalizadas para este fim, fazendo com que as políticas sociais perdessem força.

Assim, é possível reconhecer três momentos de difusão dos direitos sociais no Brasil: entre 1930 e 1964 encontra-se o período de bem-estar corporativo, no qual foram implementadas as legislações trabalhista e previdenciária; entre 1964 e 1984 encontra-se o período do universalismo básico, quando houve unificação e ampliação da cobertura previdenciária para estratos sociais anteriormente excluídos e o surgimento de planos de saúde privados; e o período do universalismo estendido, após a entrada em vigor da Constituição Federal de 1988, que institucionalizou a Assistência Social, ficou um mínimo social, previu a 
extensão da cobertura previdenciária não-contributiva, criou o Sistema Único de Saúde e a política de valorização do salário mínimo (KERSTENETZKY, 2012, p. 181).

A partir daí, Kerstenetzky explica que a pauta de direitos sociais

(...) foi paulatinamente (ainda que incompletamente) sendo introduzida ao longo das duas últimas décadas e desde o início representou pressão fiscal considerável. Sob regime de baixo crescimento, alto endividamento público e hiperinflação, esse foi um dos campos da batalha política posterior: descartado o tradicional financiamento inflacionário e por endividamento das políticas públicas, a implementação dos preceitos constitucionais, significando gastos crescentes, passaria a confrontar os que propunham a contenção de gastos e a desconstitucionalização de direitos aos que defendiam a criação de encargos apostando no financiamento tributário. No fim das contas, prevaleceu este último. Com alguns percalços, a carga tributária como proporção do PIB cresceu, entre 1988 e 2010, cerca de 12 pontos percentuais, superando o patamar de $34 \%$ do PIB, de modo a acomodar os crescentes gastos sociais e os ainda maiores encargos financeiros do governo relativos ao refinanciamento da dívida pública (2012, p. 213).

Nota-se, portanto, que políticas de crescimento econômico geram estagnação das políticas sociais e vice-versa. Conforme ressaltava Habermas já em 1987, espera-se encontrar um equilíbrio entre o desenvolvimento do Estado social e a modernização via economia de mercado (1987, p. 110). Espera-se até hoje. Segundo referido doutrinador, em observação que poderia ser empregada na atualidade,

O desenvolvimento do Estado social acabou num beco sem saída. Com ele esgotaram-se as energias da utopia de uma sociedade do trabalho. (...) O projeto do Estado social voltado para si, dirigido não apenas à moderação da economia capitalista, mas também à domesticação do Estado mesmo, perde, porém, o trabalho como seu ponto central de referência. (...) Tal barreira no intercâmbio entre sistema e mundo da vida só poderia funcionar se ao mesmo tempo adviesse uma nova partilha do poder. As sociedades modernas dispõem de três recursos que podem satisfazer suas necessidades no exercício do governo: o dinheiro, o poder e a solidariedade. As esferas de influência desses recursos teriam de ser postas em um novo equilíbrio. Eis o que quero dizer: o poder de integração social da solidariedade deveria ser capaz de resistir às "forças" dos outros dois recursos, dinheiro e poder administrativo (1987, p. 112).

Pode-se afirmar que

A visão paradisíaca que oferece um ordenamento de seguridade social termina onde acaba a idealidade platônica, porque o fato é que a porta que conduz a este ordenamento se fecha com a chave dos meios financeiros. Uma proteção de todas as necessidades e extensa a todos os cidadãos, que gravite sobre o Estado, requer extraordinários meios financeiros que, possivelmente a consciência de solidariedade de nenhum pais esteja hoje em condições de suportar"” (PASTOR apud NETTO, 2002, p. 41)

Revista de Direitos Sociais, Seguridade e Previdência Social| e-ISSN: 2525-9865 | Minas Gerais | v. 1 | n. 2 | p. 158 - 187 | Jul/Dez. 2015. 
Embora o Estado-Providência não possa ser subsumido à Seguridade Social, não há como dissociar as crises que acometem ambos, bem como estas da necessidade das reformas previdenciárias. Conforme explica Netto, as razões da crise da Seguridade Social são de índole:

1) estrutural, decorrentes da transição demográfica da sociedade (envelhecimento médio da população); b) conjuntural, decorrentes de problemas econômico-sociais (mudanças no mercado de trabalho); e c) administrativas, decorrentes de problemas com órgãos e entidades envolvidos (desvios de recursos e de má gestão do sistema) (2002, p. 86)

De forma mais detalhada, Derzi elenca quatro grupos de motivos ensejadores da crise previdenciária:

a) Atuariais, uma vez que precocemente o Brasil introduziu a aposentadoria por tempo de serviço, desvinculada da idade do trabalhador, alongando-se em demasia a sua duração.

b) Administrativos, pois a burocracia, a corrupção, o empreguismo e o nepotismo agigantaram os órgãos previdenciários, elevando-se o seu custo.

c) Caixa, pois desvios de recursos da previdência social para outras finalidades do Estado advieram de lacunas existentes na Constituição de 1967-69; o caixa da previdência social confundiu-se com o caixa do Tesouro Nacional e seus recursos foram canalizados até para construção de hidroelétricas.

d) Econômicos - conjunturais ou estruturais, desencadeados pelas crises de recessão, desemprego e queda dos salários no produto interno bruto, o que provoca o acentuado decréscimo no produto da arrecadação das contribuições previdenciárias, incidente sobre a massa dos salários (apud ARAÚJO NETTO, 2013)

Desta forma, conclui-se que "as reformas da Previdência Social são um processo constante e permanente para adequação dos sistemas às modificações socioeconômicas, demográficas e no mercado de trabalho (...) com vistas à redução dos gastos sociais” (CASTRO; LAZZARI, 2013, p. 1116).

No contexto de crise e de reformas previdenciárias é importante ressaltar que estas devem respeitar o mínimo existencial. “A retórica do mínimo existencial não minimiza os direitos sociais, senão que os fortalece extraordinariamente na sua dimensão essencial" (TORRES, 2001, p. 264). Desta forma, há que se ter em mente um núcleo duro de direitos previdenciários - a previdência básica ou fundamental. Tavares (2014, p. 38-39) explica que

A previdência fundamental deve ser baseada nos princípios da universalidade, da uniformidade e da solidariedade na proteção dos segurados mais desvalidos, mediante participação do Estado; na cobertura dos riscos sociais da morte, da idade avançada, da incapacidade, da maternidade e do desemprego involuntário; e no estabelecimento de

Revista de Direitos Sociais, Seguridade e Previdência Social| e-ISSN: 2525-9865 | Minas Gerais | v. 1 | n. 2 | p. 158 - 187 | Jul/Dez. 2015. 
patamares mínimo e máximo de pagamento os benefícios, com a manutenção real do valor das prestações.

Esses parecem ser os requisitos mínimos para a configuração da previdência como direito fundamental e os principais alicerces sobre os quais deve ser estruturada. Com o atendimento desses pressupostos, a previdência torna-se um forte instrumento de concretização do fundamento constitucional da dignidade humana e dos objetivos de erradicação da pobreza e de redução de desigualdades sociais, possibilitando o acesso às oportunidades e garantindo cidadania. Como previdência básica, pode ser comparada a um patamar mínimo abaixo do qual ninguém deve recear cair, mas acima do qual podem surgir e florescer desigualdades sociais apoiadas na autonomia privada e no talento individual.

(...) Essa, portanto, é a previdência fundamental. É o limite mínimo de proteção securitária pública e é o limite aquém do qual o Estado não pode se desonerar na proteção da sociedade.

Partindo do pressuposto de que a previdência fundamental deve ser respeitada, as reformas previdenciárias precisam se ater a este limite mínimo. É a partir desta conclusão, portanto, que se analisará os dispositivos da Lei 13.135/2015 que estabeleceu novas regras para concessão do benefício da pensão por morte.

\section{DO BENEFÍ́CIO PREVIDENCIÁRIO DA PENSÃO POR MORTE - CONSIDERAÇÕES GERAIS E FUNDAMENTO PARA SUA CONCESSÃO}

A Constituição Federal de 1988, em seu art. 6º , determina que "são direitos sociais a educação, a saúde, a alimentação, o trabalho, o lazer, a segurança, a previdência social, a proteção à maternidade e à infância, a assistência aos desamparados”, na forma por ela estabelecida. Em seus artigos 201 e seguintes traz os dispositivos que regem a Previdência Social, ressaltando como suas principais características a natureza contributiva e compulsória, assim como a obrigatoriedade de se existir um equilíbrio financeiro e atuarial para a manutenção do sistema previdenciário.

Pode-se dividir a Previdência Social em três seguimentos: o regime básico, constituído pelo Regime Geral da Previdência Social (RGPS); os chamados Regimes Próprios de Previdência Social (RPPS's); e o Regime Complementar de Previdência Social, denominado Regime Privado.

O Regime Geral de Previdência Social, instituído por lei, é de natureza compulsória: a partir do momento em que passa exercer atividade remunerada, desde que não esteja vinculada a 
nenhum regime próprio de previdência, está automaticamente vinculado a verter contribuições ao sistema previdenciário, independentemente de sua vontade. Uma exceção a esta regra são os segurados facultativos que, independente de exercerem qualquer atividade remunerada, optam por vincularem-se ao regime de previdência em busca de segurança em caso de eventos fortuitos e de amparo na velhice.

O desenvolvimento da temática proposta neste estudo concentra-se no Regime Geral de Previdência Social, mantido pelo Poder Público e de responsabilidade da União Federal. Tal regime é administrado pelo Instituto Nacional do Seguro Social (INSS), autarquia federal que possui vínculo com Ministério da Previdência Social, sendo o mesmo responsável por gerir a arrecadação, assim como os pagamentos dos benefícios concedidos aos seus segurados.

O benefício previdenciário da pensão por morte é aquele pago aos dependentes do segurado, em decorrência de seu falecimento. Assim, trata-se de um benefício cuja destinação não é dada ao próprio segurado, mas aos seus dependentes, visando ampará-los diante da ausência deste em razão de óbito. Frise-se, portanto, que a dependência econômica é fundamental para a concessão do benefício sob comento. Neste sentido, Ibrahim deixa claro que “a pensão por morte é benefício direcionado aos dependentes do segurado, visando à manutenção da família no caso da morte do responsável pelo seu sustento” (2015, p. 672) (sem destaque no original).

Tendo o óbito do segurado como fato gerador, a pensão por morte justifica-se pela vulnerabilidade de seus dependentes diante da perda do responsável pela manutenção econômica do núcleo familiar.

Além dos já mencionados dispositivos constitucionais, a Lei 8.213/91 dispõe sobre a Previdência Social, prevendo os critérios essenciais para a concessão dos benefícios concedidos pelo Regime Geral Previdência Social. Especificamente sobre a pensão por morte, tais critérios concentram-se nos artigos 74 a 79 da legislação supracitada, assim como nos artigos 105 a 115 do Decreto 3048/99.

Assim, há previsão legal de que tal benefício também será concedido aos dependentes do segurado em caso de morte presumida declarada judicialmente. Excepcionalmente, comprovando-se que o desaparecimento ocorreu em virtude de acidente, catástrofe ou desastre, o benefício será concedido aos dependentes do segurado independente de declaração de ausência. 
Possuindo previsão desde a Lei Eloy Chaves, o valor do benefício, a princípio, era de $50 \%$ (cinquenta por cento) da aposentadoria em caso de segurados com mais de trinta anos de serviço ou em caso de acidente, e de $25 \%$ (vinte e cinco por cento) da aposentadoria nos caso em que o segurado possuía entre dez e trinta anos de contribuição. Com o passar do tempo e a evolução da legislação, o benefício chegou ao patamar de $100 \%$ (cem por cento) do valor da aposentadoria recebida pelo segurado, ou da aposentadoria por invalidez a que teria direito.

O pagamento do benefício é feito aos dependentes a partir da habilitação dos mesmos junto à Previdência. Neste procedimento administrativo, a comprovação da morte do segurado é feita mediante apresentação de certidão de óbito ou da declaração judicial de ausência, em caso de morte presumida.

A qualidade de segurado do instituidor da pensão também é um requisito essencial, uma vez que não estando o trabalhador vinculado ao Regime Geral de Previdência Social (RGPS) os dependentes do mesmo não receberão o respaldo do Órgão Previdenciário. Porém, insta ressaltar que tal critério comporta exceção, prevista no artigo 102, $\S 2^{\circ}$ da Lei 8.213/91, que traz a hipótese de concessão de pensão por morte aos dependentes do segurado, ainda que este não possuísse qualidade de segurado na data do óbito, se preenchidos os requisitos para a concessão do benefício de aposentadoria nos termos do parágrafo primeiro do mesmo artigo.

Acerca dos dependentes, o artigo 16 da Lei 8.213/91 traz um rol dos possíveis beneficiários, obedecendo uma ordem de sucessão. Assim, se um dependente de primeira classe se habilita para o recebimento do benefício, somente os dependentes da mesma classe poderão pleitear sua quota, ficando automaticamente excluídos os demais. Assim, poderão ser beneficiários:

I - o cônjuge, a companheira, o companheiro e o filho não emancipado, de qualquer condição, menor de 21 (vinte e um) anos ou inválido ou que tenha deficiência intelectual ou mental que o torne absoluta ou relativamente incapaz, assim declarado judicialmente;

II - os pais;

III - o irmão não emancipado, de qualquer condição, menor de 21 (vinte e um) anos ou inválido ou que tenha deficiência intelectual ou mental que o torne absoluta ou relativamente incapaz, assim declarado judicialmente;

(...)

$\S 2^{\circ}$. O enteado e o menor tutelado equiparam-se a filho mediante declaração do segurado e desde que comprovada a dependência econômica na forma estabelecida no Regulamento.

$\S 3^{\circ}$ Considera-se companheira ou companheiro a pessoa que, sem ser casada, mantém união estável com o segurado ou com a segurada, de acordo com o $\S 3^{\circ}$ do art. 226 da Constituição Federal. 
Com relação ao $\$ 3^{\circ}$, frise-se que abarca as uniões entre pessoas do mesmo sexo estabelecidas de forma pública, duradoura e com ânimo de constituir família, uma vez que a Portaria MPS no 513, de 09 de dezembro de 2010, assim determinou.

Ainda com referência ao art. 16 da Lei 8.213/91, seu $\S 4^{\circ}$ esclarece que a dependência econômica das pessoas indicadas no inciso I é presumida, devendo os demais comprovarem a mesma em caso de requerimento do benefício. Ademais, o $\S 4^{\circ}$ do art. 75 do mesmo diploma legal prevê que o cônjuge divorciado ou separado judicialmente ou de fato que recebia pensão alimentícia do segurado falecido concorrerá em igualdade de condições com os dependentes referidos no inciso I do art. 16 acima transcrito.

Quanto a estes três critérios - morte enquanto fato gerador do benefício e definição das categorias de segurado e dependentes - a Medida Provisória 664/14, convertida na Lei 13.135/2015, trouxe apenas uma alteração, relativa ao inciso III, passando a ser considerado beneficiário "o irmão de qualquer condição menor de 21 (vinte e um) anos ou inválido ou que tenha deficiência intelectual ou mental ou deficiência grave, nos termos do regulamento". Foi acrescida a expressão “deficiência grave”. Em seu turno, a Lei 13.146/2015, publicada no Diário Oficial em 07/07/2015 e que tem prazo de vacatio legis de 180 dias, fez as seguintes alterações no art. 16 da Lei 8.213/91:

\footnotetext{
Art. 16. (...)

I. o cônjuge, a companheira, o companheiro e o filho não emancipado, de qualquer condição, menor de 21 (vinte e um) anos ou inválido ou que tenha deficiência intelectual ou mental ou deficiência grave.

(...)

III. o irmão não emancipado, de qualquer condição, menor de 21 (vinte e um) anos ou inválido ou que tenha deficiência intelectual ou mental ou deficiência grave.
}

Relativamente às demais classes de dependentes a nova legislação não trouxe nenhuma alteração. Contudo, o benefício em análise passou a ter outras critérios de concessão mais rígidos, sob o argumento da necessidade de realização de ajuste fiscal nas contas da União, bem como da prevenção de fraudes contra a sistema previdenciário.

A pensão por morte não dependia de tempo mínimo de carência para ser concedida, bastando o instituidor estar vinculado ao regime, ou seja, possuir a qualidade de segurado. Tal situação justificava-se sob o argumento de que o evento morte é uma fatalidade, podendo ocorrer a qualquer momento, dificultando o planejamento financeiro dos segurados e gerando grande risco

Revista de Direitos Sociais, Seguridade e Previdência Social| e-ISSN: 2525-9865 | Minas Gerais | v. 1 | n. 2 | p. 158 - 187 |

Jul/Dez. 2015. 
social. Porém, com a edição da Medida Provisória 664/2014 passou-se a exigir um tempo mínimo de carência de 2 anos e, sequencialmente, a Lei 13.135/2015 diminuiu este prazo para 18 meses, excetuando-se os casos em que a morte decorrer de acidente de qualquer natureza ou de doença profissional ou do trabalho.

Outra inovação trazida pela Lei 13.135 foi a previsão de que cônjuge ou companheiro(a) só terão direito à pensão por morte durante 4 meses caso sua união com o segurado falecido não tenha durado, ao menos, 2 anos. Exceção a esta regra será feita quando o óbito do segurado tenha se dado em virtude de acidente de qualquer natureza ou de doença profissional ou do trabalho.

Comprova-se o casamento mediante apresentação de certidão de casamento e a existência de união estável através da apresentação de documentos constantes no rol do artigo

$22, \S 3^{\circ}$ do Decreto 3048/99. Assim,

§ 3을 Para comprovação do vínculo e da dependência econômica, conforme o caso, devem ser apresentados no mínimo três dos seguintes documentos:

I - certidão de nascimento de filho havido em comum;

II - certidão de casamento religioso;

III - declaração do imposto de renda do segurado, em que conste o interessado como seu dependente;

IV - disposições testamentárias;

$\mathrm{V}$ - (revogado)

VI - declaração especial feita perante tabelião;

VII - prova de mesmo domicílio;

VIII - prova de encargos domésticos evidentes e existência de sociedade ou comunhão nos atos da vida civil;

IX - procuração ou fiança reciprocamente outorgada;

$\mathrm{X}$ - conta bancária conjunta;

$\mathrm{XI}$ - registro em associação de qualquer natureza, onde conste o interessado como dependente do segurado;

XII - anotação constante de ficha ou livro de registro de empregados;

XIII - apólice de seguro da qual conste o segurado como instituidor do seguro e a pessoa interessada como sua beneficiária;

XIV - ficha de tratamento em instituição de assistência médica, da qual conste o segurado como responsável;

XV - escritura de compra e venda de imóvel pelo segurado em nome de dependente;

XVI - declaração de não emancipação do dependente menor de vinte e um anos; ou XVII - quaisquer outros que possam levar à convicção do fato a comprovar.

Outro ponto questionável nas alterações impostas pela nova lei é o que se refere à tabela progressiva que atrela o período de duração do benefício à idade do beneficiário pertencente à categoria de cônjuge ou companheiro(a) à época do óbito do segurado. Se até a edição da MP 664/2014 e sua posterior conversão na Lei 13.135/2015 a pensão assegurada ao 
cônjuge/companheiro sobrevivente era vitalícia, independentemente de sua idade, a partir da novel legislação a mesma passa a ser temporária na maioria dos casos, de acordo com a idade do dependente.

De acordo com a referida tabela, tendo o beneficiário menos de 21 anos à data do óbito do segurado, receberá pensão por morte durante 3 anos; tendo entre 21 e 26 anos, receberá a pensão por 6 anos; tendo entre 27 e 29 anos, será pensionado por 10 anos; tendo entre 30 e 40 anos, receberá o benefício por 15 anos; tendo entre 41 e 43 anos, a pensão será paga durante 20 anos; e, por fim, a pensão será vitalícia se o beneficiário contar com 44 anos ou mais.

Tais alterações seguem a tendência de vários outros países, a saber:

No caso dos EUA, a pensão somente é concedida à viúva(o) a partir dos 60 anos de idade, não pode acumular com a aposentadoria, assim como se impõem regras específicas de carência contributiva. A França adota padrão semelhante. A idade mínima é de 55 anos de idade e a(o) pensionista deve estar casada(o) com o instituidor há pelo menos dois anos. Pode-se acumular pensão com aposentadoria, mas, para receber o benefício, o pensionista deve ter renda inferior a 15 mil euros por ano.

Alguns países adotam limites mínimos apenas para o período contributivo. No Canadá, com outras carências, impõe-se um período contributivo mínimo de três anos. Na Alemanha e na Itália a carência é de cinco anos. No Chile, demandam-se três anos de contribuição e casamento. Na Argentina o período mínimo de convivência com o instituidor é de cinco anos, ou dois, se ambos têm ao menos um filho em comum. Junto a isso, para as pensões por morte em atividade, exige-se um mínimo de 30 contribuições nos últimos 36 meses.

A Suécia é um caso peculiar porque somente se paga pensão por um período de dez meses, além de se exigir pelo menos três anos de residência no país.

No México é necessária a dependência econômica para o recebimento do benefício, casamento de pelo menos um ano e ao menos 150 semanas de contribuição na data do falecimento do instituidor, e o benefício cessa em caso de casamento do pensionista (CAETANO, 2006, p. 25).

A Lei 13.135/2015 acrescentou, ainda, os $\$ \S 1^{\circ}$ e $2^{\circ}$ ao art. 74 da Lei 8.213/91, passando a prever que "perde o direito à pensão por morte, após o trânsito em julgado, o condenado pela prática de crime que tenha dolosamente resultado a morte do segurado" $\left(\S 1^{\circ}\right)$ e que também perderá este direito:

o cônjuge, o companheiro ou a companheira se comprovada, a qualquer tempo, simulação ou fraude no casamento ou na união estável, ou a formalização desses com o fim exclusivo de constituir benefício previdenciário, apuradas em processo judicial no qual será assegurado o direito ao contraditório e à ampla defesa. $\left(\S 2^{\circ}\right)$

Revista de Direitos Sociais, Seguridade e Previdência Social| e-ISSN: 2525-9865 | Minas Gerais | v. 1 | n. 2 | p. 158 - 187 | Jul/Dez. 2015. 
Por fim, saliente-se que o valor do benefício da pensão por morte permaneceu equivalente a 100\% (cem por cento) da aposentadoria recebida pelo segurado, ou daquela que teria direito se estivesse aposentado por invalidez na data de seu falecimento, sendo repartido em quotas iguais entre todos os dependentes que fazem jus ao benefício. Perdendo um dos dependentes a condição de beneficiário, sua quota será repartida entre os demais.

A Lei 13.135/2015 não recepcionou o texto da Medida Provisória 664/2014 que previa que o valor da renda mensal inicial (RMI) do benefício passaria a ser de 50\% (cinquenta por cento) da aposentadoria recebida pelo segurado, ou a que teria direito, sendo acrescido de quotas individuais de 10\% (dez por cento) por dependente, até o máximo de cinco.

Embora não tenha sido acolhido pela Lei 13.135/2015, o principal argumento para a redução do percentual da pensão era o de que, com a morte do segurado, as despesas do núcleo familiar seriam reduzidas. Conforme destaca Martins (2015, p. 387),

\footnotetext{
Afirma-se que o coeficiente de cálculo da pensão não deveria ser de $100 \%$, pois, com a morte do segurado, há menores despesas com alimentação, transporte, saúde etc. Esse argumento é relativo, em razão de que, se a família é numerosa, a saída de uma pessoa ainda assim implica o recebimento do benefício integral. Se o percentual for reduzido, a família tem prejuízo, pelo fato de que a receita familiar será menor.
}

$\mathrm{O}$ argumento adotado pelo doutrinador segue a lógica econômica atual das famílias brasileiras. Grande parte das famílias, ainda que numerosas, possuem renda per capita de valor muito abaixo do esperado. Assim sendo, a saída de um dos integrantes em nada interfere nas despesas domésticas, e diminuir o valor da renda a ser recebida poderia ferir os direitos constitucionais destes cidadãos, os colocando em situação de miserabilidade. Portanto, neste aspecto, merece elogios a nova legislação por não ter encampado as prescrições da MP $664 / 2014$.

\section{ANÁLISE CRÍTICA DAS NOVAS REGRAS PARA CONCESSÃO DA PENSÃO POR MORTE AO CÔNJUGE/COMPANHEIRO(A) SOB A PERSPECTIVA DO DIREITO DE FAMÍLIA - CONCILIANDO SUSTENTABILIDADE PREVIDENCIÁRIA E SOLIDARIEDADE FAMILIAR}

Com o intuito de desonerar a Previdência Social, promover o equilíbrio notarial ${ }^{3}$ e evitar fraudes à mesma, conforme mencionado no capítulo anterior a Lei 13.135/2015 trouxe duas

Revista de Direitos Sociais, Seguridade e Previdência Social| e-ISSN: 2525-9865 | Minas Gerais | v. 1 | n. 2 | p. 158 - 187 | Jul/Dez. 2015. 
situações polêmicas como a determinação de que cônjuge e companheiro(a) do segurado falecido só receberá pensão por morte durante 4 meses caso a união tenha durado menos de 2 anos, bem como a criação de uma tabela progressiva relativa ao tempo de duração do gozo do referido benefício previdenciário, pautada na idade do beneficiário à época do óbito do segurado.

Como tais providências dizem respeito a beneficiários que assim podem ser considerados por terem vivenciado relacionamento amoroso com o segurado, tendo manifesto ânimo de constituir família, o Direito de Família pode e deve ser evocado para uma análise mais aprofundada de tais medidas.

Tal interface entre os dois âmbitos do ordenamento jurídico brasileiro não é rara e, em alguns casos, o Direito Previdenciário atuou na vanguarda do Direito de Família, como diante do reconhecimento expresso das uniões homoafetivas, uniões paralelas e dos filhos socioafetivos para fins previdenciários. Tal fato demonstra que o Direito Previdenciário está atento às novidades do Direito de Família, donde se conclui que, por um lapso, o legislador pátrio ignorou as semelhanças entre a pensão por morte e a pensão alimentícia, bem como as implicações ideológicas destas semelhanças. É justamente por este motivo que o presente artigo propõe uma análise crítica das novidades trazidas pela Lei $13.135 / 2015$ à concessão da pensão por morte ao cônjuge/companheiro(a).

Se se pretende traçar um comparativo entre pensão por morte e pensão alimentícia (alimentos), esta precisa ser devidamente conceituada, uma vez que aquela já o foi no capítulo anterior.

"Segundo Orlando Gomes, alimentos são prestações para satisfação das necessidades vitais de quem não pode provê-los por si” (DINIZ, 2013, p. 635) e devem compreender as

\footnotetext{
${ }^{3}$ Conforme estabelece a exposição de motivos da Medida Provisória n. 664/2014, convertida na Lei 13.135/2015, "2. Cabe salientar que, em função do processo de envelhecimento populacional, decorrente da combinação de queda da fecundidade e aumento da expectativa de vida, haverá um aumento da participação dos idosos na população total e uma piora da relação entre contribuintes e beneficiários. A participação dos idosos na população total deverá crescer de $11,3 \%$, em 2014, para 33,7\% em 2060, conforme dados da projeção demográfica do IBGE. Como resultado, o relatório de avaliação atuarial e financeira do RGPS, que faz parte dos anexos do Projeto de Lei de Diretrizes Orçamentárias (PLDO), estima o crescimento da despesa, em \% do PIB, do atual patamar de 7\% para cerca de 13\% em 2050. O artigo 201 da Constituição estabelece que a Previdência Social deverá ser organizada sob a forma de regime geral, de caráter contributivo e de filiação obrigatória, observados critérios que preservem o equilíbrio financeiro e atuarial" (ALVES FILHO; BELCHIOR; MANTEGA, 2014, p. 1)
}

Revista de Direitos Sociais, Seguridade e Previdência Social| e-ISSN: 2525-9865 | Minas Gerais | v. 1 | n. 2 | p. 158 - 187 | Jul/Dez. 2015. 
necessidades vitais do indivíduo - alimentação, saúde, moradia, vestuário lazer, educação - em prol da manutenção de sua dignidade. "Em breve síntese, os alimentos devem ser concebidos dentro da ideia de patrimônio mínimo (...)” (SIMÃO; TARTUCE, 2008, p.3 94).

Segundo prevê o art. 1.694 do Código Civil, podem os parentes, os cônjuges ou companheiros pedir uns aos outros os alimentos de que necessitem para viver de modo digno e compatível com a sua condição social, devendo a fixação dos mesmos observar as necessidades do reclamante e as possibilidades financeiras da pessoa obrigada. Por sua vez, o art. 1.696 também do Código Civil, determina que "o direito à prestação de alimentos é recíproco entre pais e filhos, e extensivo a todos os ascendentes, recaindo a obrigação nos mais próximos em grau, uns em falta de outros". Conforme ressaltam Gagliano e Pamplona Filho,

A obrigação alimentar, vale acrescentar, também é sucessiva, entendida tal característica na circunstância de que, na ausência de ascendentes, passaria para os descendentes e, na ausência destes últimos, aos irmãos, assim germanos (ou seja, irmãos dos mesmo pai e mãe) quanto unilaterais, na forma do art. 1.697 CC-02 (2015, p. 693694)

Com relação à obrigação de pensionamento do ex-cônjuge/companheiro, o dever de prestar alimentos cessará se o alimentado contrair novo casamento ou união estável. Frise-se que com relação ao credor, cessa, também, o direito a alimentos se tiver procedimento indigno contra a pessoa do devedor (arts. 1.708 e 1.1709 do Código Civil).

A fixação dos alimentos sempre poderá ser revista se houver modificação na situação financeira de quem os presta e/ou recebe, havendo possibilidade de exoneração, redução ou majoração dos mesmos.

Traçadas estas considerações básicas sobre o instituto da pensão alimentícia, pode-se dizer que ela e a pensão por morte possuem os mesmos fundamentos: a solidariedade e a dependência econômica. Neste sentido, Pereira explica que

Todo indivíduo tem direito à subsistência. Primordialmente, pelo trabalho, cujo exercício livre é assegurado constitucionalmente (...) Quem não pode prover à sua subsistência, nem por isto é deixado à própria sorte. A sociedade há de propiciar-lhe sobrevivência, através de meios e órgãos estatais ou entidades particulares. Ao Poder Público compete desenvolver a assistência social, estimular o seguro, tomar medidas defensivas adequadas. (...) Mas o direito não descura o fato da vinculação da pessoa ao seu próprio organismo familiar. E impõe, então, aos parentes do necessitado, ou pessoa a ele ligada por um elo civil, o dever de proporcionar-lhe as condições mínimas de sobrevivência, não como favor ou generosidade, mas como obrigação judicialmente 
exigível. (...) O fundamento originário desta obrigação é o vínculo da "solidariedade familiar" (...) (2007, p. 495-496).

A solidariedade familiar, derivação da solidariedade social enquanto fundamento da República Federativa do Brasil, deve reger as relações familiares independentemente do tempo de duração do vínculo familiar. É o dever de solidariedade familiar que faz nascer o dever de pagamento de pensão alimentícia entre parentes. Segundo explica Rolf Madaleno (2008, p. 64), "a solidariedade é princípio e oxigênio de todas as relações familiares e afetivas, porque esses vínculos só podem se sustentar e se desenvolver em ambiente recíproco de compreensão e cooperação, ajudando-se mutuamente sempre que se fizer necessário”.

Nas palavras de Dias,

Solidariedade é o que cada um deve ao outro. Esse princípio, que tem origem nos vínculos afetivos, dispõe de conteúdo ético, pois contem em suas entranhas o próprio significado da expressão solidariedade, que compreende a fraternidade e a reciprocidade. A pessoa só existe quando coexiste. O princípio da solidariedade tem assento constitucional, tanto que seu preâmbulo assegura uma sociedade fraterna. Também ao ser imposto aos pais o dever de assistência aos filhos (CF 229), consagra-se o princípio da solidariedade. O dever de amparo às pessoas idosas (CF 230) dispõe do mesmo conteúdo solidário. A lei civil consagra o princípio da solidariedade ao dispor que o casamento estabelece plena comunhão de vidas (CC 1.511). Igualmente a obrigação alimentar dispõe deste conteúdo (CC 1.694) (2009, p. 66)

Por fim, Barbosa acrescenta que:

A preservação da vida é, seguramente, a mais importante proteção atribuída ao Direito. E a expressão desta proteção, em sua forma mais essencial para a vida é a garantia de meios materiais ao indivíduo, tais a alimentação, o vestuário, o abrigo etc. Em princípio, a pessoa obtém os maios materiais de que necessita através de seu trabalho ou renda de seus capitais. No entanto, há duas situações que exigem que outros promovam este sustento, dando origem aos três modos de previsão de alimentos em Direito de Família: alimentos dos pais aos filhos menores, alimentos entre ex-cônjuges ou ex-companheiros e aqueles decorrentes de relações familiares entre maiores de idade (2008, p. 226)

Além da semelhança entre os fundamentos da solidariedade e da dependência econômica, pensão por morte pensão alimentícia possuem, praticamente, os mesmos beneficiários/credores. A pensão por morte será devida ao cônjuge; ao(à) companheiro(a) (união estável ou homoafetiva); ao(à) filho(a) menor de 21 anos que não seja emancipado(a) e, em qualquer idade, se for inválido ou tenha deficiência intelectual ou mental que o torne incapaz; aos pais; ao(à) irmão(ã) menor de 21 anos que não seja emancipado(a) e, em qualquer idade, se for inválido ou 
tenha deficiência intelectual ou mental que o torne incapaz; o enteado e menor tutelado, desde que comprovada a dependência econômica; ex-cônjuge e ex-companheiro(a) que recebia pensão alimentícia do segurado falecido à época do óbito.

Com relação aos credores de pensão alimentícia pode-se listar os ex-cônjuges e excompanheiros (união estável ou homoafetiva); os pais; os filhos (de qualquer natureza); os netos; e os irmãos. Com relação aos filhos, a regra é que o pensionamento cesse aos dezoito anos, mediante autorização judicial, sendo doutrina e jurisprudência pacíficas com relação à prorrogação do direito caso esteja cursando curso superior ou técnico-profissionalizante. Relativamente aos netos, os avós possuem obrigação complementar em termos de pensionamento e serão chamados se os pais não puderem arcar com a manutenção da subsistência dos filhos. Com relação aos irmãos, só serão acionados para prestar alimentos se não houver parentes em linha reta que possam fazê-lo. Na linha colateral de parentesco a lei prevê (arts. 1.696 e 1.697, Código Civil) que a obrigação alimentar subsiste até o segundo grau e, portanto, se encerraria na categoria dos irmãos, não atingindo tios, sobrinhos e primos. Contudo, existem posicionamentos doutrinários divergentes, sobretudo porque o parentesco colateral é considerado até o quarto grau para fins sucessórios.

Outra semelhança entre as pensões alimentícia e por morte reside no fato de que decorrem de situações fáticas que geram a vulnerabilidade daqueles que, respectivamente, serão considerados credores e beneficiários.

Por fim, exemplificando que o Direito Previdenciário é atento ao Direito de Família, através do $\S 1^{\circ}$ do art. 74 da Lei 13.135/2015 passou a prever que, após o trânsito em julgado da sentença condenatória, perde o direito à pensão por morte o condenado pela prática de crime de que tenha dolosamente resultado a morte do segurado. O Código Civil de 2002 já prevê, há mais de dez anos, que com relação ao credor de alimentos cessa o direito de recebimento da pensão alimentícia se tiver procedimento indigno em relação ao devedor (parágrafo único do art. 1.708).

Demonstradas as inúmeras semelhanças entre a pensão por morte e a pensão alimentícia, passar-se-á à crítica do novo regramento da pensão por morte ao cônjuge/companheiro(a) dado pela Lei 13.135, com o intuito de contribuir para o aperfeiçoamento desta. A crítica, embora envolva vários dispositivos do referido diploma legal, resume-se na manutenção da presunção de dependência econômica de certos beneficiários em tempos de crise do Estado-Providência, já

Revista de Direitos Sociais, Seguridade e Previdência Social| e-ISSN: 2525-9865 | Minas Gerais | v. 1 | n. 2 | p. 158 - 187 |

Jul/Dez. 2015. 
que a mesma promove fraudes à Previdência quando não há referida dependência econômica entre o cônjuge/companheiro(a) e o segurado falecido.

Com relação à previsão de que o pensionamento será de apenas 4 meses ao cônjuge/companheiro(a) caso sua união com o segurado falecido não tenha atingido duração mínima de 2 anos, importante destacar que este requisito não condiz com o Direito de Família contemporâneo.

Certamente o legislador pátrio, ao prever tempo mínimo de duração do casamento e da união estável para que o cônjuge/companheiro(a) supérstite tenha direito ao benefício da pensão por morte teve como justificativa evitar uniões de "fachada"4 que tenham como único intuito o desfrute de benefícios previdenciários. É muito comum a situação em que idosos que não possuem nenhum dependente que se enquadre nos parâmetros exigidos na legislação previdenciária aceitem se casar ou registrar em cartório união estável com pessoas próximas para garantir-lhes o benefício da pensão por morte.

Ao estipular o tempo mínimo de dois anos de casamento ou união estável para fins de concessão de pensão por morte, a Lei 13.135/2015 está em consonância com a Convenção n $^{\circ} 102$ da Organização Internacional do Trabalho (OIT) que, no art. 63, item 5, determina a possibilidade de fixação de duração mínima do casamento para que um viúva sem filhos, presumidamente incapaz de prover sua própria subsistência, tenha direito à pensão por morte.

No âmbito do Direito de Família a preocupação relativa ao casamento do idoso preocupa seus familiares, mais ainda os seus herdeiros, a ponto de a Lei restringir sua liberdade e imporlhe o regime da separação total de bens obrigatório ou legal. Neste cenário, a lei tem como objetivo proteger o idoso, seus familiares e seus bens da ação de pessoas de má-fé. Já no caso da pensão por morte o golpe não é aplicado ao idoso, mas à Previdência Social, de forma que é necessário reprimir este tipo de conduta.

4 Conforme explica o item 7 da Exposição de Motivos da Medida Provisória 664/2014, convertida na Lei 13.135/2015, "De igual maneira, é possível a formalização de relações afetivas, seja pelo casamento ou pela união estável, de pessoas mais idosas ou mesmo acometidas de doenças terminais, com o objetivo exclusivo de que o benefício previdenciário recebido pelo segurado em vida seja transferido a outra pessoa. Ocorre que a pensão por morte não tem a natureza de verba transmissível por herança e tais uniões desvirtuam a natureza da previdência social e a cobertura dos riscos determinados pela Constituição Federal, uma vez que a sua única finalidade é de garantir a perpetuação do benefício recebido em vida para outra pessoa, ainda que os laços afetivos não existissem em vida com intensidade de, se não fosse a questão previdenciária, justificar a formação de tal relação. Para corrigir tais distorções se propõe que formalização de casamento ou união estável só gerem o direito a pensão caso tais eventos tenham ocorrido 2 anos antes da morte do segurado, ressalvados o caso de invalidez do cônjuge, companheiro ou companheira após o início do casamento ou união estável, e a morte do segurado decorrente de acidente" (ALVES FILHO; BELCHIOR; MANTEGA, 2014, p. 3). 
Ademais, a estipulação de tempo mínimo de relacionamento também tem fundamento no fato de que se a união é recente, o beneficiário poderia muito bem retomar o padrão de vida que possuía antes daquela. Contudo, isso não pode ser tido como verdade absoluta. Um exemplo bastante comum é o de que pessoas recém casadas ou que passaram a viver união estável recentemente se endividam com gastos relativos à celebração da união, viagem de lua-de-mel e montagem da casa onde vão residir. Nestas circunstâncias de aperto financeiro pode ser que um dos cônjuges venha a óbito e o outro se veja completamente vulnerável economicamente. Estas pessoas podem ser jovens e sadias e nunca terem pensado em fraudar a Previdência através de uma união simulada. Ainda assim, o viúvo ou a viúva só terão direito a 4 meses de pensão por morte, considerando que a união não chegou a durar 2 anos.

Para a uniões simuladas que objetivam fraudar a Previdência, a Lei 13.135/2015 incluiu o $\S 2^{\circ}$ no art. 74 da Lei 8.213/91 que, conforme mencionado anteriormente, passou a prever que perderá o benefício tanto o cônjuge quanto o companheiro(a) se for comprovada, a qualquer tempo, simulação ou fraude na união ou se sua formalização tiver como fundamento exclusivo a constituição do benefício previdenciário. Logicamente tal fato só poderá ocorrer mediante apuração em processo judicial, garantido o contraditório e a ampla defesa.

Portanto, se a simulação ou a fraude do casamento ou da união estável forem comprovadas, cessará o pagamento da pensão por morte. Este dispositivo legal bastaria para coibir uniões fraudulentas. Um adendo poderia ser feito à legislação para complementar esta regra: o processo judicial de apuração de fraude deveria ter trâmite preferencial e um rito diferenciado, considerando que uma possível fraude contra a Previdência não pode se perpetuar no tempo.

Teria sido mais justo o legislador se, ao invés de desconfiar de todas as uniões com duração inferior a 2 anos à data do óbito do segurado, tivesse simplesmente afastado a presunção de dependência econômica entre cônjuges/companheiros, mantendo-a apenas com relação aos filhos menores de 21 anos, filhos maiores declarados judicialmente absoluta ou relativamente incapazes, bem como ao cônjuge divorciado ou separado judicialmente ou de fato que recebia pensão alimentícia do segurado falecido.

Qual o motivo da presunção de dependência econômica para fins previdenciários no caso de cônjuge e companheiro(a) se, no âmbito do Direito de Família, o magistrado analisa a necessidade de quem reclama os alimentos antes de concedê-los? Se o cônjuge ou companheiro sobrevivente não necessitar de pensão alimentícia em caso de divórcio ou desconstituição da união 
estável, por que subsistiria a presunção de dependência econômica para fins de concessão da pensão por morte?

Segundo ressalta Cezar Fiúza (2008, p. 982), “os alimentos deverão ser prestados em caso de necessidade. Ninguém será obrigado a alimentar pessoa saudável, em condições de trabalhar e prover o próprio sustento".

Nesta mesma linha de raciocínio, Rolf Madaleno (2008, p.441-442) destaca que

Os alimentos entre cônjuges estão cada vez mais escassos, especialmente diante da igualdade constitucional, resumindo-se o crédito alimentar para situações pontuais de necessidade efetiva, quando o cônjuge não dispõe de condições financeiras e tampouco de oportunidades no mercado de trabalho, em razão da idade, ou da falta de experiência, e quando os filhos conjugais ainda são pequenos e dependem da atenção materna.

A obrigação alimentar entre os cônjuges é recíproca e sua pauta está atrelada à situação fática da efetiva necessidade (...). (sem destaque no original)

Desta forma, a Previdência Social também deveria analisar se realmente há dependência econômica que sustente a necessidade de concessão da pensão por morte ao cônjuge e ao companheiro.

Saliente-se que o artigo $2^{\circ}$. da Lei 8.213/91 elenca os princípios que regem a Previdência Social e, dentre eles, importante destacar o Princípio da seletividade e distributividade na prestação dos benefícios. Segundo Ibrahim (2015, p. 68),

Os direitos sociais costumam receber o rótulo de direitos positivos, isto é, direitos que demandam determinada ação do governo, ao contrário dos direitos negativos clássicos do Estado liberal, que constituem obrigações negativas, como não intervir na esfera de liberdade do indivíduo.

Os direitos positivos trazem um custo maior para o Estado, já que os direitos negativos são, basicamente, deveres de abstenção do Poder Público. Daí, o crescimento das obrigações positivas trouxe, com maior evidência, o conhecido princípio da Reserva do Possível, o qual traz limitação à atuação estatal, dentro das possibilidades orçamentárias.

Caberá ao Legislador efetuar as escolhas trágicas, ou seja, definir na lei orçamentária onde aplicar os limitados recursos, dentro das ilimitadas demandas da sociedade. Neste contexto insere-se a seletividade, impondo a concessão e manutenção das prestações sociais de maior relevância, levando-se em conta os objetivos constitucionais de bemestar e justiça social.

Para Wagner Balera, a seletividade atua na delimitação do rol de prestações, ou seja, na escolha dos benefícios e serviços a serem mantidos pela seguridade social, enquanto a distributividade direciona a atuação do sistema protetivo para as pessoas com maior necessidade, definindo o grau de proteção. (...)

Algumas prestações serão extensíveis somente a algumas parcelas da população, como, por exemplo, salário-família (exemplo de seletividade) e, além disto, os benefícios e

Revista de Direitos Sociais, Seguridade e Previdência Social| e-ISSN: 2525-9865 | Minas Gerais | v. 1 | n. 2 | p. 158 - 187 | Jul/Dez. 2015. 
serviços devem buscar a otimização da distribuição de renda no pais, favorecendo pessoas e regiões mais pobres (exemplo de distributividade).

Assim, a análise da efetiva dependência econômica dos cônjuges e companheiros e não sua dependência presumida, ajudariam a equacionar a aplicação do princípio acima descrito. $\mathrm{O}$ raciocínio é lógico: se cônjuges e companheiros que não necessitam da pensão por morte deixarem de recebê-la, sobrarão mais recursos a serem distribuídos pela Previdência Social na forma de benefícios.

Na contramão deste raciocínio de que a dependência econômica não deve ser presumida, Ibrahim sustenta que "o melhor seria a legislação já determinar a conversão automática da aposentadoria do segurado em pensão por morte (...), como já se prevê para o auxílio-reclusão, no art. 118 do RPS” (2015, p. 674). Embora o autor não esteja se referindo, especificamente à conversão de aposentadoria em pensão por morte para beneficiar cônjuge/companheiro(a), importante ressaltar que a aposentadoria é um benefício concedido ao próprio segurado e a pensão por morte aos dependentes do mesmo em caso de dependência econômica. A dependência econômica também é o fator determinante para que a família do segurado preso receba o auxílio-reclusão. Portanto, os dependentes em caso de morte serão os mesmos no caso de prisão do segurado, o que autoriza a conversão automática do benefício. Em ambos os casos a lei determina ser a dependência econômica determinante para a concessão dos benefícios.

Não obstante seja desejável otimizar o tempo para concessão de benefícios previdenciários e diminuir o número de processos administrativos e judiciais em âmbito previdenciário, não se pode agilizar esta prestação a todo custo, sem considerar as despesas desnecessárias que serão efetuadas com benefícios concedidos em decorrência de presunção de dependência econômica.

Portanto, nos casos de pensão por morte entre cônjuges e companheiros há que se debruçar sobre os casos concretos e apurar se há efetiva dependência econômica entre segurado e beneficiário, sob pena de onerar a Previdência desnecessariamente. Certamente, quando da criação do benefício sob comento, eram poucas as mulheres inseridas no mercado de trabalho, ficando a maioria delas adstrita aos trabalhos domésticos. Portanto, justificava-se a presunção de dependência econômica entre em tal contexto. Em outras palavras, a dependência econômica da mulher em relação ao marido/companheiro em tempos pretéritos era legítima, mas não se pode afirmá-la na atualidade sem a análise do caso concreto. 
Outra alteração trazida pela Lei 13.135/2015 relaciona-se ao tempo de duração da concessão da pensão por morte. O benefício que, até então, possuía caráter vitalício em relação ao cônjuge/companheiro sobrevivente, passa a ser temporário, obedecendo o tabelamento feito pela Previdência ${ }^{5}$, salvo se o beneficiário contar com 44 anos ou mais, caso em que a regra anterior permanecerá.

Com relação ao estabelecimento do caráter temporário da pensão por morte, importante destacar que se encontra em consonância com o que vem sendo praticado na seara do Direito de Família, conforme anteriormente ressaltado.

Conforme explica Rolf Madaleno (2008, p. 443-444),

Muito é dito acerca dos alimentos transitórios nos casamentos e nas uniões estáveis judicialmente desfeitos, idealizados com o propósito de assegurar por algum tempo o alimento destinado ao cônjuge ou convivente desprovido de emprego e recursos financeiros, dotado, contudo, de capacidade e de condições de buscar, em curto espaço de tempo, emprego e rendimento no mercado de trabalho e assim prover a própria subsistência.

Para Marco Aurélio Gastaldi Buzzi, há uma forte tendência em estabelecer entre cônjuges e conviventes um termo transitório para a obrigação alimentar, vazado no fundamento de que, "na atualidade, não mais se justifica impor a uma das partes integrantes da comunhão desfeita a obrigação de sustentar a outra, de modo vitalício, quando aquela reúne condições para prover a sua própria manutenção”. (...)

Para Marco Aurélio Viana, não é viável transformar o instituto dos alimentos em fonte vitalícia de ócio, quando todo ser humano deve trabalhar para a sua sobrevivência, embora admita, para determinados casos, possam os alimentos ser fixados por um Período de tempo razoável para o credor carrear os meios destinados a subsidiar sua existência. (...)

O termo final da pensão alimentícia pode coincidir com a conquista de um emprego, ou com o início de uma atividade liberal remunerada, isso quando os juízes não estabelecem a contagem do tempo por determinado Período, ou por alguns anos, considerados suficientes para o alimentando superar os usuais percalços verificados na transição sempre penosa entre a separação e a obtenção de um emprego.

Alcançada a condição projetada na sentença, extingue-se automaticamente o direito alimentar, independentemente do ajuizamento de ação de exoneração, ou de revisão (...).

\footnotetext{
${ }^{5}$ Conforme consta da Exposição de Motivos da Medida Provisória nº 664/2014, “10. Submetemos, também, à apreciação de Vossa Excelência, que o prazo de duração da pensão por morte varie em função da idade do dependente (...), sendo reduzida a duração do benefício quanto maior seja a expectativa de sobrevida (...). (...) a medida visa estimular que o dependente jovem busque seu ingresso no mercado de trabalho, evitando a geração de despesa a conta do RGPS para pessoas em plena capacidade produtiva, permitindo, ao mesmo tempo, o recebimento de renda por certo período para que crie as condições necessárias ao desenvolvimento de atividade produtiva" (ALVES FILHO; BELCHIOR; MANTEGA, 2014, p. 3).
} 
Ilustrando este posicionamento, tem-se os seguintes acórdãos do Superior Tribunal de

Justiça:

PROCESSO CIVIL E DIREITO CIVIL. FAMÍLIA. ALIMENTOS. AÇÃO DE SEPARAÇÃO JUDICIAL LITIGIOSA. IMPUTAÇÃO DE CULPA. VIOLAÇÃO DOS DEVERES DO CASAMENTO. PRESUNÇÃO DE PERDÃO TÁCITO. ALIMENTOS TRANSITÓRIOS. ATUALIZAÇÃO MONETÁRIA. 1. A presunção de perdão tácito declarada pelo TJ/MG constitui circunstância fática imutável na via especial, a teor da Súmula $n^{0}$ 7/ STJ. 2. A boa-fé objetiva deve guiar as relações familiares, como um manancial criador de deveres jurídicos de cunho preponderantemente ético e coerente. 3. De acordo com os arts. 1.694 e 1.695 do CC/02, a obrigação de prestar alimentos está condicionada à permanência dos seguintes pressupostos: (I) o vinculo de parentesco, ou conjugal ou convivencial; (II) a necessidade e a incapacidade do alimentado de sustentar a si próprio; (III) a possibilidade do alimentante de fornecer alimentos. 4 . $O$ fosso fático entre a Lei e o contexto social impõe ao Juiz detida análise de todas as circunstâncias e peculiaridades passíveis de visualização ou de intelecção no processo, para a imprescindível aferição da capacidade ou não de auto-sustento daquele que pleiteia alimentos, notadamente em se tratando de obrigação alimentar entre excônjuges ou ex-companheiros. Disso decorre a existência ou não da presunção da necessidade de alimentos. 5. A realidade social vivenciada pelo casal ao longo da união deve ser um fator determinando para a fixação dos alimentos. Mesmo que se mitigue a regra inserta no art. 1.694 do CC/02, de que os alimentos devidos, na hipótese, são aqueles compatíveis coma condição social do alimentando, não se pode albergar o descompasso entre o status usufruído na constância do casamento ou da união estável e aquele que será propiciado pela atividade laborativa possível. 6. A obrigação de prestar alimentos transitórios - a tempo certo - é cabível, em regra, quando o alimentando é pessoa com idade, condições e formação profissional compatíveis com uma Possível inserção no mercado de trabalho, necessitando dos alimentos apenas até que atinja sua autonomia financeira, momento em que se emancipará da tutela do alimentante outrora provedor do lar -, que será então liberado da obrigação, a qual se extinguirá automaticamente. 7. Nos termos do art. 1.710 do $\mathrm{CC} / 02$, a atualização monetária deve constar expressamente da decisão concessiva de alimentos, os quais podem ser fixados em numero de salários mínimos. Precedentes. 8. Recurso Especial parcialmente provido (STJ, $3^{\mathrm{a}}$. Turma, REsp 1.025.769-MG, Rel. Min. Fátima Nancy Andrighi, j. 24/08/2010) .

CIVIL E PROCESSUAL CIVIL. ALIMENTOS. EXONERAÇÃO. INEXISTÊNCIA DE ALTERAÇÃO NO BINÔMIO NECESSIDADE/POSSIBILIDADE. 1- Os alimentos devidos entre ex-cônjuges serão fixados com termo certo, a depender das circunstâncias fáticas próprias da hipótese sob discussão, assegurando-se, ao alimentando, tempo hábil para sua inserção, recolocação ou progressão no mercado de trabalho, que lhe possibilite manter pelas próprias forças, status social similar ao período de relacionamento. 2- Serão, no entanto, perenes, nas excepcionais circunstâncias de incapacidade laboral permanente ou, ainda, quando se constatar, a impossibilidade prática de inserção no mercado de trabalho. 3- Em qualquer uma das hipóteses, sujeitam-se os alimentos à cláusula rebus sic stantibus, podendo os valores serem alterados quando houver variação no binômio necessidade/possibilidade. 4- Se os alimentos devidos a ex-cônjuge não foram fixados por temo certo, o pedido de desoneração total, ou parcial, poderá dispensar a existência de variação por lapso temporal suficiente para que o alimentando revertesse a condição desfavorável que detinha, no momento da fixação desses alimentos. 5- Recurso especial provido (STJ, $3^{\mathrm{a}}$. Turma, REsp 1.205.408-RJ, Rel. Min. Fátima Nancy Andrighi, j. 21/06/2011).

Revista de Direitos Sociais, Seguridade e Previdência Social| e-ISSN: 2525-9865 | Minas Gerais | v. 1 | n. 2 | p. 158 - 187 | Jul/Dez. 2015 
Assim, como tanto a pensão por morte quanto a pensão alimentícia possuem caráter alimentar, estando o cônjuge/companheiro beneficiário em condições de se manter independentemente do pensionamento, não subsiste razão para que o mesmo seja concedido ou, se já concedido, mantido.

Embora, neste aspecto, a Lei 13.135/2015 esteja de acordo com a atual tendência do Direito de Família, o que se questiona é a criação de uma tabela fixando o tempo de duração do benefício, considerando somente a faixa etária do dependente e sua expectativa de vida.

O que se esperava é que fosse feita análise do caso concreto antes da fixação do período de duração do benefício concedido ao cônjuge/companheiro(a) do segurado falecido.

Há que se ter em mente que o simples fato de o cônjuge ou companheiro(a) ser jovem e estar em idade economicamente ativa, não esclarece, por si só, a verdade dos fatos. Muitas vezes este dependente possui impedimentos que não o permitem ingressar no mercado de trabalho e, consequentemente, auferir renda para sua mantença. Do mesmo modo, muitas vezes um cônjuge/companheiro(a), já em idade avançada, possui renda própria, não dependendo economicamente do segurando falecido, nem mesmo antes do falecimento deste. Contudo, nestes casos será concedido ao dependente de forma vitalícia ou por longos anos benefício ao qual, numa análise atenta ao caráter alimentar da pensão, não teria direito.

Em uma comparação com o Direito de Família, onde os alimentos são de caráter personalíssimo, não se pode aceitar o tabelamento do benefício de pensão por morte, vez que a regra aplicada de forma geral não leva em consideração a individualidade do dependente, sendo potencialmente causadora de injustiças sociais.

\section{CONSIDERAÇÕES FINAIS}

Utilizando como cenário a crise do Estado-Providência ou Estado de Bem-Estar Social, bem como a crise da Previdência Social no Brasil, o presente estudo teve como objetivo propor uma reflexão sobre o novo regramento da pensão por morte entre cônjuges e companheiros tendo como fio condutor o paralelo entre a pensão por morte, inerente ao Direito Previdenciário, e a pensão alimentícia, inerente ao Direito de Família, considerando que ambas possuem a mesma natureza alimentar. 
A partir da Exposição de Motivos da Medida Provisória nº 664/2014, convertida, com algumas alterações, na Lei $\mathrm{n}^{\mathrm{o}} 13.135 / 2015$ - que trouxe as novas normas regulamentadoras para concessão do benefício da pensão por morte - percebeu-se preocupação expressa no sentido de evitar fraudes à Previdência Social e com o equilíbrio atuarial, sendo este um dos princípios que a regem.

Embora a novel legislação seja louvável em vários aspectos aqui ressaltados, como a previsão da pensão por morte temporária, uma crítica deve ser feita: parte do pressuposto de que há dependência econômica entre cônjuges/companheiros; de que todo casamento/união estável que não tenha completado 2 anos de duração à época do óbito do segurado merece desconfiança por parte do Poder Público; e de que a idade do cônjuge/companheiro(a) do segurado falecido é determinante para a fixação do lapso temporal em que fará jus ao recebimento da pensão, independentemente da análise das peculiaridades do caso concreto.

Embora se saiba que quanto mais objetivos os critérios para concessão dos benefícios previdenciários, mais rapidamente tramitam os procedimentos para sua concessão, esta objetividade, em determinados casos, pode significar injustiças.

A presunção de dependência econômica entre cônjuges pode trazer agilidade à concessão da pensão por morte, mas, sob outra perspectiva, afigura-se, potencialmente, uma possibilidade de fraude à Previdência legitimada pela própria legislação previdenciária.

Se, no caso da pensão alimentícia, a fixação da pensão alimentícia deve observar o binômio possibilidade financeira do alimentante-necessidades materiais do alimentado, no caso da pensão por morte não se pode perder de vista que a mesma sai de um "caixa" comum, e que este responsabiliza-se pelo custeio da Saúde, Assistência Social e Previdência Social. Portanto, quanto menos gastos desnecessários, mais próxima ao ideal do Estado-Providência estará a Seguridade Social.

A análise do caso concreto antes da concessão da pensão por morte é medida que encontra fundamento tanto no princípio do equilíbrio notarial quanto no princípio da seletividade e distributividade.

Portanto, foram detectados 3 pontos frágeis e questionáveis na Lei 13.135/2015 no que concerne à pensão por morte ao cônjuge/companheiro(a): a) para evitar fraudes decorrentes de casamentos ou uniões estáveis "de fachada" que visam apenas à aquisição de direitos previdenciários, o legislador considerou determinante o tempo de duração da união, de forma 
que se a mesma não tiver completado pelo menos 2 anos na data do óbito do segurado o cônjuge/companheiro(a) receberá o benefício por apenas 4 meses. Se não há dependência econômica entre ambos, qual o motivo de o cônjuge/companheiro supérstite receber a pensão por morte?; b) a presunção de dependência econômica é inconcebível tratando-se de benefício de caráter alimentar; e c) ainda que a fixação da pensão temporária seja uma tendência à concessão da pensão alimentícia e que, de forma saudável, poderia ser importada pelo Direito Previdenciário, critica-se o tabelamento prévio referente à duração do benefício que consta da Lei 13.135/2015. Se o tabelamento não leva em conta as peculiaridades do caso concreto, ignora a real aferição da dependência econômica. Acredita-se, sim, na possibilidade de uma pensão por morte transitória, mas o período de sua duração deveria ser analisado de forma individualizada.

Acredita-se que as considerações aqui tecidas, não obstante a dificuldade logística de implementação da análise das peculiaridades do caso concreto antes da concessão da pensão por morte entre cônjuges e companheiros, podem contribuir para a sustentabilidade da Seguridade Social e para o enfrentamento da crise do Estado de Bem-Estar Social.

\section{REFERÊNCIAS}

ALVES FILHO, Garibaldi; BELCHIOR, Miriam Aparecida; MANTEGA, Guido. Exposição de Motivos $n^{o}$ 00023/2014 MPS/MF/MP. Disponível em:

http://www.planalto.gov.br/ccivil_03/_Ato2011-2014/2014/Mpv/mpv664.htm . Acesso em $16 / 08 / 2015$.

ARAÚJO NETO, Raul Lopes de. Crise da previdência social brasileira: considerações sobre os fatores que comprometem a prestação dos serviços e benefícios previdenciários. Disponível em: http://www.publicadireito.com.br/artigos/?cod=4b01078e96f65f2a . Acesso em 05/07/2015.

ASSEMBLÉIA GERAL DAS NAÇÕES UNIDAS. Declaração Universal dos Direitos do Homem, 1948. Disponível em: http://unesdoc.unesco.org/images/0013/001394/139423por.pdf. Acesso em 21/07/2015.

BARBOSA, Águida Arruda. Alimentos. In: BARBOSA, Águida Arruda; STEIN, Cláudia (Coords.). Direito Civil: direito de família, vol. 7. São Paulo: Revista dos Tribunais, 2008, p. 226-239.

BENEVIDES, CLÁUDIA DO VALLE. Um Estado de bem-estar social no Brasil? 2011. $97 \mathrm{f}$. Dissertação (Mestrado em Economia). Centro de Ciências Sociais Aplicadas, Universidade Federal Fluminense, $\quad$ Niterói. $2011 . \quad$ Disponível em: 
http://www.proac.uff.br/cede/sites/default/files/EBES_no_Brasil_2_dissertacao_benevides.pdf. Acesso em: 23/05/2015.

CAETANO, Marcelo Abi-Ramia. Determinantes da sustentabilidade e do custo previdenciário: aspectos conceituais e comparações internacionais. Brasília: IPEA, Texto para Discussão 1.226, 2006. Disponível em: http://core.ac.uk/download/pdf/6225581.pdf . Acesso em 13/06/2015.

CASTRO, Carlos Alberto Pereira de; LAZZARI, João Batista. Manual de Direito Previdenciário 15 ${ }^{\mathrm{a}}$. Ed rev. e atual. Rio de Janeiro: Forense, 2013.

DIAS, Maria Berenice. Manual de Direito das Famílias. $5^{\text {a }}$ ed. São Paulo: Editora Revista dos Tribunais, 2009.

DINIZ, Maria Helena. Curso de direito civil brasileiro, v. 5: direito de Família. 28ª . Ed. São Paulo: Saraiva, 2013.

FIORI, José Luís. Estado de bem-estar social: padrões e crises. In Physis - Revista de Saúde Coletiva, $\mathrm{n}^{\mathrm{o}} .7$, vol. 2, Rio de Janeiro, 1997, p. 129-147. Disponível em: http://www.scielo.br/pdf/physis/v7n2/08.pdf. Acesso em 10/08/2015.

FIUZA, Cezar. Direito civil: curso completo. 11 ed. rev., atual. e ampl. Belo Horizonte: Del Rey, 2008.

GAGLIANO, Pablo Stolze; PAMPLONA FILHO, Rodolfo. Direito civil, v. 6: direito de família - as famílias em perspectiva constitucional. $5^{\text {a }}$. Ed. rev. e atual. São Paulo: Saraiva, 2015.

GARLAND, David. A cultura do controle: Crime e ordem social na sociedade contemporânea. Tradução de André Nascimento. Rio de Janeiro: Renavan, 2008.

HABERMAS, Juergen. A nova intransparência: a crise do estado de bem-estar social e o esgotamento das energias utópicas. In: Revista Novos Estudos, n ${ }^{\circ}$. 18, set/1987, p.103-114. Disponível em: http://novosestudos.uol.com.br/v1/files/uploads/contents/52/20080623_a_nova_intransparencia.p df. Acesso em 10/06/2015.

HORVATH JÚNIOR, Miguel. Salário maternidade: à luz da proteção previdenciária. São Paulo: Quatier Latin, 2004.

IBRAHIM, Fábio Zambitte. Curso de Direito Previdenciário. 20 ed. Niterói: Impetus, 2015.

MADALENO, Rolf. Curso de direito de família. Rio de Janeiro: Forense, 2008.

. Alimentos e sua configuração atual. In: RIBEIRO, Gustavo Pereira Leite; TEIXEIRA, Ana Carolina Brochado (Coords.). Manual de direito das famílias e das sucessões. Belo Horizonte: Del Rey, Mandamentos, 2008, p. 425-452. 
MARTINS, Sergio Pinto. Direito da Seguridade Social: Custeio da Seguridade Social Benefícios - Acidente do Trabalho - Assistência Social - Saúde. 35 ed. São Paulo: Atlas, 2015.

NETTO, Juliana Presotto Pereira. A previdência social em reforma: o desafio da inclusão de um maior numero de trabalhadores. São Paulo: LTr, 2002.

PEREIRA, Caio Mário da Silva. Instituições de direito civil, vol. V: direito de família. $16^{\mathrm{a}}$ ed. rev. e atual. por Tânia da Silva Pereira. Rio de Janeiro: Forense, 2007.

RAMOS, Edith Maria Barbosa. Reforma neoliberal e seguridade social: breves anotações sobre a America Latina. In: p. 3464- 3470. Disponível em: Acesso em: 05/06/2015.

SIMÃO, José Fernando; TARTUCE, Flávio. Direito civil, v. 5: direito de família, $3^{\mathrm{a}}$. Ed. rev e atual. Rio de Janeiro: Forense; São Paulo: Método, 2008.

SUPERIOR TRIBUNAL DE JUSTIÇA, $3^{\text {a. }}$ Turma, REsp 1.025.769-MG, Rel. Min. Fátima Nancy Andrighi, j. 24/08/2010.

SUPERIOR TRIBUNAL DE JUSTIÇA, $3^{\text {a. }}$ Turma, REsp 1.205.408-RJ, Rel. Min. Fátima Nancy Andrighi, j. 21/06/2011.

TAVARES, Marcelo Leonardo. Direito Previdenciário. 15ª Ed. Niterói: Impetus, 2014.

TORRES, Ricardo Lobo. A cidadania multidimensional na era dos direitos. In: TORRES, Ricardo Lobo (Coord.). Teoria dos direitos fundamentais. Rio de Janeiro: Renovar, p. 243-342. 